DOI: $10.17951 /$ lrp. 2017.36 .4 .65

\title{
Grażyna Penkowska
}

Uniwersytet Gdański

\section{CYFROWY UCZEŃ WE WSPÓŁCZESNEJ SZKOLE - DYSKUSJA O OBECNYM STANIE EDUKACJI}

\begin{abstract}
Streszczenie: Określenie „przeciążenie informacyjne”, które Alvin Toffler umieścił w książce Szok przyszłości wydanej po raz pierwszy w 1970 roku, było wówczas zwrotem futurystycznym (Toffler, s. 316). Z perspektywy prawie półwiecza utopijna wizja Tofflera dziś jest rzeczywistością. Znaczący udział w narastaniu zjawiska przeciążenia informacyjnego odgrywają nowoczesne technologie informacyjno-komunikacyjne. Musimy więc zadać sobie pytanie, jak powinna się zmieniać współczesna edukacja, gdzie postawić granicę przy włączaniu nowoczesnych technologii do pracy ze studentami. Niniejszy artykuł zawiera rozważania dotyczące diagnozy zjawiska przeładowania informacyjnego oraz próbę określenia pozycji nauczyciela w cyfrowym świecie. Współcześni uczniowie stali się swoistymi zakładnikami nowoczesnych technologii, ale nie zawsze przekłada się to na lepszą jakość kształcenia.
\end{abstract}

Słowa kluczowe: cyfrowy uczeń, środowisko sieciowe, urządzenia mobilne, wielozadaniowość

\section{ŚRODOWISKO SIECIOWE CYFROWEGO UCZNIA}

„Szok przyszłości” to nie tylko tytuł książki Alvina Tofflera, ale także opis konsekwencji szybkich zmian społecznych przebiegających w zbyt krótkim czasie. O stresie społecznym jako reakcji na problemy adaptacyjne związane z zawrotnymi przemianami technologicznymi pisał w teorii „opóźnienia kulturowego” amerykański socjolog Wiliam Ogburn w połowie XX wieku (Toffler, s. 15). Wskazywał on na możliwość występowania napięć w obrębie różnych grup społecznych w związku z ograniczonymi możliwościami człowieka radzenia sobie ze zmianami. Te napięcia przekładają się na zakłócenia w różnych sferach ludzkiej działalności, sprzyjając konfliktom. Podobne niepokoje można zauważyć współcześnie między różnymi grupami społecznymi, np. wiekowymi, grupami o różnym statusie społecznym czy odmiennych zainteresowaniach. Często nowoczesne technologie wzmacniają 
te napięcia, dzieląc ludzi na nowoczesnych, domyślnie - używających technologii, i przestarzałych - zacofanych, niemodnych.

Najbardziej rewolucyjną zmianą XXI wieku jest digitalizacja wszystkich sfer życia człowieka. Z danych opublikowanych przez agencję badawczą We Are Social w raportach z 2015 i 2016 roku wynika jednoznacznie, że rok 2014 był przełomowy dla wszystkich obszarów związanych z cyfrowością, mobilnością i mediami społecznościowymi (Digital in 2016; Digital, Social and Mobile in 2015). Kolejne lata następujące po roku 2014 cechuje stały wzrost udziału technologii informacyjno-komunikacyjnych w różnych dziedzinach życia, w tym głównie w zakresie liczby użytkowników Internetu i urządzeń mobilnych oraz korzystania z serwisów społecznościowych. Raport Digital, Social \& Mobile Worldwide in 2015 sygnalizował pojawienie się tych zmian, a kolejny Digital in 2016 w pełni potwierdził tendencję ucyfrowienia różnych obszarów życia współczesnego człowieka. Ostatnie z przywołanych opracowań, raport ze stycznia 2016 roku, zawiera dane statystyczne na temat digitalizacji różnych sfer życia zebrane z 232 krajów świata. $Z$ zaprezentowanych informacji wynika, że blisko 3,4 mld ludzi korzysta $z$ Internetu, 2,3 mld jest aktywnych w mediach społecznościowych, 3,7 mld używa telefonów komórkowych, a 1,9 mld korzysta mobilnie z mediów społecznościowych (liczba ludzi na świecie przekroczyła wg tego samego raportu 7,3 mld). We wszystkich rozpatrywanych obszarach zauważono wzrost o co najmniej 10\% w stosunku do stycznia 2015 roku, a liczba korzystających mobilnie z mediów społecznościowych wzrosła aż o 17\% w stosunku do roku 2015. Zebrane przez agencję We Are Social dane są ważne dla firm produkujących sprzęt informacyjno-komunikacyjny i oprogramowanie, bo pokazują, jak chłonny jest rynek, jeśli chodzi o technologie. Jednak znaczenie danych zawartych w raportach jest istotne także dla nauk społecznych. W obszarze edukacji zainteresowanie wdrażaniem nowoczesnych technologii nie jest zbyt wielkie. Trudno precyzyjnie określić kierunek przemian edukacji i czy będzie on czerpał energię z potencjału mobilnych technologii. Coraz bardziej uwidacznia się zbyt małe wykorzystanie nowoczesnych technologii do wsparcia procesu kształcenia na wszystkich szczeblach edukacji.

Środowisko sieciowe jest przeciążone informacjami i coraz częściej do jego opisu używa się terminu smog informacyjny. W zastosowanym tu metaforycznym znaczeniu smog odnosi się zarówno do redundancji, jak i zanieczyszczenia środowiska informacyjnego. Redundancja to przeładowanie informacją, odpowiednik zadymienia (dym - ang. smoke), a zanieczyszczenie (zamglenie, mgła - ang. fog) środowiska informacyjnego człowieka to umieszczanie w nim informacji niejasnych, nieprawdziwych lub szkodliwych. Smog informacyjny tworzy się w konsekwencji nieustannego bombardowania informacjami z różnych źródeł (bilbordy, telewizja, komputer, urządzenia mobilne), w różnych formatach (wizualnym, wizualno-gło- 
sowym, tekstowym i głosowym) i o różnym stopniu zanieczyszczenia informacjami nieprawdziwymi. Smog informacyjny jest równie szkodliwy jak smog atmosferyczny, wprowadza dezinformację, zagubienie w sieci, „zatruwa” cyberprzestrzeń. Jest też jednym z powodów zachowawczego stosunku wielu nauczycieli do szerokiego użycia w edukacji ogólnie dostępnych zasobów sieciowych. Jednak odrzucenie lub ograniczenie użycia nowoczesnych technologii mobilnych w edukacji formalnej nie wpłynie najprawdopodobniej na zmniejszenie liczby użytkowników tych technologii na co dzień, a spowoduje utratę możliwości edukacyjnych, jakie one dają. Decyzja szerszego niż do tej pory włączenia technologii do procesu kształcenia wydaje się być jedyną rozsądną w kontekście tak szybkiego tempa wzrostu liczby użytkowników technologii mobilnych. Prognozy na rok 2016 wskazują na wzrost o ponad 1,5 mld liczby nowych smartfonów (IDC: prognozy rynku smartfonów w 2016 roku).

W Internecie spędzamy bardzo dużo czasu. Według badań firmy Global Web Index, założonej w 2009 roku przez Toma Smitha i dostarczającej danych firmom reklamowym, każdego dnia internauci w wieku 18-32 lat spędzają w sieci 7 godzin i 43 minuty (Mobile Web Usage Highest Among Teens and Millennials 2015). Gdyby ten czas choćby w części był wykorzystany na samokształcenie kierowane, nie byłoby poczucia bezproduktywnego surfowania po sieci.

Terminy cyfrowość, uczeń i informacja są obecnie kluczowe w edukacji. Nieustanna zmienność środowiska edukacyjnego zmusza, by poddawać je stale namysłowi i badaniu z różnych perspektyw. Można je rozpatrywać dwubiegunowo: zalety vs wady. Inna droga analizy kontekstu zagadnień to podkreślanie korzyści z jednoczesnym marginalizowaniem zagrożeń lub straszenie konsekwencjami zmian bez uwzględniania obecnego stanu rzeczy. Zwiększenie liczby urządzeń mobilnych, wzrost liczby użytkowników tych urządzeń i czasu codziennego użytkowania sieci przekonuje do szerszego niż do tej pory włączania do edukacji.

Liczba użytkowników Internetu na świecie (46\%), choć bardzo różna dla poszczególnych krajów, ciągle rośnie (Digital, Social and Mobile in 2015). Prym wiodą Zjednoczone Emiraty Arabskie, w których internauci to 96\% społeczeństwa, w Wielkiej Brytanii - 92\%, Kanadzie - 91\%. W Polsce 67\% obywateli korzysta z Internetu. Najniższe wskaźniki dostępności do Internetu według raportu We Are Social z 2016 roku mają: Korea Północna - 0,03\% użytkowników (7200), Niger - 2\%, Czad - 2,5\%.

Skoro każdego dnia 27 mln Polaków korzysta z Internetu, jest w tej aktywności zamrożony ogromny potencjał intelektualny, który jest w dużej mierze rozproszony i niezamieniany w żaden mierzalny efekt. Co więcej, najliczniejszą grupą spędzającą ponad 7 godzin w sieci każdego dnia są osoby w wieku od 17 do 32 lat (Mobile web usage highest among Teens and Millennials 2015). Są to uczniowie, studenci i młodzi pracownicy, grupa zawodowa najbardziej nastawiona na samorozwój. 


\section{DZIECI I TABLETY}

Urządzenia mobilne wykorzystywane są chętnie przez dzieci i to nawet małe, w wieku 0-6 lat. Wskazują na to wyniki badań ilościowych przeprowadzonych na zlecenie Fundacji Dzieci Niczyje przez agencję badawczą Millward Brown S.A. i opublikowanych w opracowaniu Korzystanie $z$ urządzeń mobilnych przez małe dzieci $w$ Polsce (Bąk 2015). Nie ma dostatecznych dowodów na to, że urządzenia mobilne szkodzą małym dzieciom, bo obecnie dostępne tablety są w użyciu stosunkowo niedawno, dopiero od 2010 roku. Dlatego nie ma szczegółowych, obejmujących większy odcinek czasowy badań nad tym zagadnieniem. Możemy w tym względzie polegać na doświadczeniach badaczy z innych krajów, m.in. USA. Według zaleceń Amerykańskiej Akademii Pediatrii dopiero powyżej drugiego roku życia można dziecku umożliwić korzystanie z tabletu (Bąk 2015, s. 4). Oznacza to dostęp $\mathrm{w}$ formie kilkuminutowych sesji w obecności i pod kontrolą rodzica. Niestety rodzice, także w Polsce, nie przestrzegają tych zaleceń, umożliwiając korzystanie z tabletów nawet dzieciom kilkumiesięcznym. Wnioski z badań 1011 rodziców polskich dzieci w wieku 0-6,5 roku są zatrważające (Bąk 2015). Pokazują one, że aż $64 \%$ badanych dzieci poniżej 6 roku życia korzysta z urządzeń mobilnych, w tym $25 \%$ codziennie, $26 \%$ dzieci posiada własne urządzenia mobilne, $79 \%$ dzieci ogląda filmy, a $62 \%$ gra na smartfonie lub tablecie, $62 \%$ rodziców pozwala dzieciom na korzystanie z urządzeń mobilnych, kiedy muszą się zająć własnymi sprawami, a $49 \%$ traktuje to jako nagrodę.

Naprzeciw oczekiwaniom rodziców dumnych z pociech wodzących palcem po ekranie i przełączających się między aplikacjami wychodzą firmy produkujące akcesoria dla niemowlaków. Proponują różne urządzenia wyposażone w tablet lub w uchwyt do smartfona dla maluchów. Jednym z takich urządzeń jest nocnik z tabletem. Gdy został zaprezentowany na targach CES 2013, gdzie przedstawiono akcesoria do tabletów i smartfonów, był przez niektórych traktowany z uśmiechem, ale coraz częściej widać, że uśmiech ten był nieuzasadniony (Sitnik 2013).

Dzieci rozpoczynające korzystanie z urządzeń mobilnych poniżej szóstego roku życia są potencjalnymi „cyfrowymi” uczniami w szkole już za kilka lat. Czy szkoła jest przygotowana na przyjęcie nowej generacji dzieci obcujących z nowoczesnymi technologiami od niemowlęctwa? Pewnie nie do końca, ale rozwój zastosowań tabletów i smarftonów o nowe funkcje wskazuje na to, że należy przyspieszyć badania dotyczące ich zastosowania w procesie kształcenia. Nowe media, o których fenomenie pisał Paul Levinson, stają się powoli starymi, a interaktywność i kooperacja w sieci nie jest już niczym niezwykłym (Levinson 2010, s. 11). Dzieci w wieku kilku lat traktują nowoczesne technologie, w tym tablety, jako oczywisty element świata, bo używają ich od niemowlęctwa. Wzrasta także wiedza o zagroże- 
niach ze strony mediów, wiedza rodziców i dzieci, szczególnie w starszych klasach szkoły podstawowej, w szkołach ponadgimnazjalnych i na uczelniach wyższych. Brak walki o prymat rozwojowy malucha często zakłóca rodzicom właściwą próbę oceny sytuacji. Szeroko zakrojone badania naukowe dotyczące negatywnego wpływu mediów na rozwój intelektualny dzieci są jednocześnie sygnałem, że ich włączanie do edukacji powinno być poddane głębszej refleksji (Demurget 2012, s. 87-172). Refleksja ta miałaby na celu nie tylko wypracowanie metod włączania urządzeń mobilnych do realizacji treści programowych różnych przedmiotów, ale jednocześnie pomogłaby wskazać odpowiedzialne sposoby integracji nowoczesnych technologii ze stosowaną do tej pory tradycyjną dydaktyką.

\section{SKUTKI UCYFROWIENIA RÓŻNYCH SFER ŻYCIA}

Gdy szukamy danych dotyczących korzystania z Internetu, zwykle interesuje nas, ile czasu spędzają badani w sieci oraz jakiego typu aktywności podejmują. Czas korzystania z Internetu współczesnych uczniów mierzony jest inaczej niż dekadę wcześniej. Wówczas łączono się z Internetem za pośrednictwem urządzeń stacjonarnych i stąd każda sesja łączenia z Internetem miała swój początek i koniec. Obecnie okres korzystania z sieci mierzy się nie godzinami surfowania po Internecie, ale szacowaniem czasu wielu krótkich połączeń w ciągu dnia, czasem kilkudziesięciu, a nawet kilkuset. Nie będzie przesady w nazwaniu tego stanu ciągłym byciem w sieci. Bo jak inaczej określić opcję stałej gotowości do odbierania i wysyłania informacji? Każdy ruch znajomych w sieci jest sygnalizowany np. dźwiękowo (Messenger). Współczesny uczeń wielokrotnie komunikuje się ze znajomymi za pośrednictwem smartfona. W każdej wolnej chwili sprawdza status znajomych na portalu społecznościowym, komentuje posty, odnosi się do treści przekazywanych przez inne kanały informacyjne (Messenger, Snapchat itp.). Stale uwikłany jest w przeróżne sprawy toczące się w sieci przy równoległym (jednoczesnym) rozwiązywaniu własnych problemów w realnym świecie. Reaguje na informacje z sieci, nawiązując rozmowę, na ogół tekstową, a równocześnie rozwiązuje zadania z matematyki, pisze klasówki, notuje na lekcjach. Po lekcjach życie cyfrowego ucznia niewiele się zmienia - uczy się, odrabia zadania domowe, wykonuje drobne prace domowe itp., będąc stale online. Stan ciągłego "przełączania się" między światem realnym i wirtualnym jest obecnie normą.

Przyjęło się nazywać łączenie kilku aktywności w sieci wielozadaniowością. Początkowo taki rodzaj funkcjonowania, charakterystyczny dla młodego pokolenia, przyjmowano jako pozytywną adaptację do nowych warunków panujących w środowisku wirtualnym. Pierwsze badania Gary'rgo Smala i Gigi Vorgan do- 
wiodły, że aktywność mózgu w trakcie surfowania po sieci jest o wiele większa niż przy czytaniu książki (Small, Vorgan 2011, s. 14). Obrazy mózgu uzyskane przez badaczy za pomocą rezonansu magnetycznego (MRI) pokazują stymulację innych obszarów mózgu w trakcie aktywności w sieci i podczas tradycyjnych aktywności umysłowych, np. czytania książki. Wyniki ich badań dowodzą nie tylko większej aktywności mózgu podczas pracy wirtualnej, ale też odmienności jej charakteru, czyli tego, że jest bardziej intensywna i zlokalizowana w innych obszarach mózgu. Pierwotnie zinterpretowano to jako postępujący proces adaptacyjny do nowoczesnych technologii, dający nadzieję na poprawę efektów uczenia się w związku ze wzmożonym stymulowaniem różnych procesów myślowych. Przemiany funkcjonowania mózgu pod wpływem stymulacji pracą w sieci to rzeczywiście proces przystosowania się do nowych warunków, jednak efekty wpływu technologii na uczenie się rozczarowały. Nie przełożyły się wprost na zdecydowany wzrost efektów kształcenia, a raczej wpłynęły negatywnie na osiągane wyniki w nauce. Dlaczego wzmożona aktywność mózgu nie przekłada się na zwiększenie efektów kształcenia? Odpowiedź na to pytanie nie jest łatwa, choć ważna dla wszystkich, w szczególności dla nauczycieli i pedagogów. Ciekawe wnioski dotyczące tożsamości młodzieży w komunikacji zdalnej, także dotyczące problematyki wielozadaniowości, zawiera raport podsumowujący projekty prowadzone w latach 2010-2015 opracowany przez Beatę Staszyńską i Onno Hansena (Raport podsumowujący wyniki projektów 2010-2015). Autorzy, opierając się na badaniach przeprowadzonych w ramach różnych projektów przez kilku uczonych (Larry Rosen, Phil Libin, Daniel Levitin, Daniel Kahneman i inni) w kilku krajach (Holandia, USA, Polska, Grecja), ujawniają różne aspekty wpływu technologii na tożsamość młodzieży w kontekście komunikacji online. Jednym z rozważanych aspektów jest wielozadaniowość. Do negatywnych cech wielozadaniowości należą m.in.:

- stałe rozproszenie, nerwowość, zniecierpliwienie, brak możliwości dłuższej niż 10-15 minut koncentracji na zadaniu,

- zmęczenie mózgu, wyczerpanie, zdezorientowanie, nerwowość, brak energii na refleksję,

- utrata pamięci krótkotrwałej i w konsekwencji długotrwałej (Raport podsumowujacy wyniki projektów 2010-2015).

Zygmunt Bauman gorzko stwierdza, że wielozadaniowość nie pozwala na zakorzenienie się wiedzy w naszych umysłach. Ocieranie się o „strzępy” wiedzy jednocześnie, $\mathrm{z}$ różnych mediów aktywizujących na krótko różne ośrodki naszego mózgu, pozostawia zaledwie ślad, który szybko znika ze struktur pamięci (Bauman 2012).

Małe to pocieszenie, że współczesna szkoła nie ponosi winy za procesy, które podobnie jak wielozadaniowość wpływają na gorszą jakość pracy i wolniejsze jej 
wykonywanie przez uczniów. Do podobnych wniosków doszedł Manfred Spitzer, który twierdzi, że wielozadaniowcy osiągają dużo gorsze wyniki w pracy od osób koncentrujących się na jednym zadaniu (Spitzer 2013, s. 204).

\section{CYFROWY UCZEŃ W SMOGU INFORMACYJNYM W OPINII STUDENTÓW I ROKU PEDAGOGIKI}

W semestrze zimowym w roku akademickim 2015/2016 w Pracowni Edukacji Medialnej w Instytucie Pedagogiki Uniwersytetu Gdańskiego przeprowadzono badania wśród studentów pierwszego roku pedagogiki. Celem badań było zebranie opinii o tym, jak funkcjonuje cyfrowy uczeń w smogu informacyjnym. Badania przeprowadzono w strategii interpretatywnej, było to studium przypadku (20 osób), zastosowano technikę analizy treści esejów napisanych przez studentów na temat, który był celem badań. Analiza treści esejów pokazała, że studenci pedagogiki są świadomą grupą, która zdaje sobie sprawę z zagrożeń, jakie niesie bezkrytyczne używanie nowoczesnych technologii. W swoich analizach wskazali na wyróżniające cechy współczesnego cyfrowego ucznia. Młodzi ludzie:

- posiadają wiele urządzeń mobilnych, telefon musi mieć dostęp do sieci i jest dobrą alternatywą spędzania czasu wolnego;

- są rozpieszczani przez rodziców, którzy kupują im najnowsze urządzenia informacyjno-komunikacyjne;

- są więźniami nowoczesnych technologii, nie potrafią się bez nich obejść;

- nie potrafią zapamiętywać faktów, zdarzeń, bo opcjonalnie mogą je znaleźć w każdej chwili, jednak po znalezieniu szybko je zapominają, charakteryzuje ich młodzieńcza demencja;

- są ciągle zmęczeni wielogodzinnymi sesjami przed komputerem;

- są stale „podłączeni”, często uzależnieni od komputera i komórki;

- nieposiadający najnowszych urządzeń mobilnych czują się wykluczeni, nikt nie chce być inny;

- wolą się uczyć z ekranu, dlatego wprowadzenie do szkół e-podręczników jest bardzo dobrym pomysłem;

- często spędzają więcej czasu przed komputerem niż z rodzicami.

Wnikliwa i krytyczna ocena sytuacji młodych związana z nadużywaniem mediów nie idzie $\mathrm{w}$ parze $\mathrm{z}$ ich decyzjami co do ograniczania czasu korzystania z sieci, bycia stale online czy odpisywania na posty. Sami przyznają, że pomimo wiedzy o negatywnym wpływie mediów na ich życie nie potrafią kontrolować czasu ich używania. Nie są w stanie zrezygnować z dostępu do Internetu ani ograniczać różnorodnej aktywności w sieci. 


\section{PODSUMOWANIE}

Stan ciągłego przełączania się między światem realnym i wirtualnym jest obecnie normą, podobnie jak przełączanie się między zadaniami równocześnie wykonywanymi w sieci. Wyniki badań zaprezentowane przez Gary’ego Smalla i Gigi Vorgan potwierdziły pozytywny wpływ codziennego używania komputerów, smartfonów, gier czy wyszukiwarek na szybszą przemianę adaptacyjną mózgów. Przemiana ta dotyczy uwalniania neuroprzekaźników i wzmacniania tworzenia nowych połączeń nerwowych przy jednoczesnym osłabieniu starszych. Jednak ciągłe zajmowanie się różnymi zadaniami na raz nie pozostaje bez konsekwencji dla pracy mózgu, który jest permanentnie przeciążany. Pojawia się obawa, że może to mieć wpływ na pojawienie się problemów z pamięcią w młodym wieku. Choroby charakterystyczne dla wieku podeszłego, takie jak demencja, zaburzona podzielność uwagi czy depresja, mogą pojawić się znacznie wcześniej. Skala problemów będzie możliwa do oszacowania w dłuższej perspektywie czasowej, gdy generacja użytkowników mediów mobilnych osiągnie wiek średni. Obecnie skutki smogu informacyjnego są różnorodne. Badania prowadzone przez wielu badaczy (m.in. Gary'ego Smalla, Manfreda Spicera czy Michaela Demurgeta) pokazują, że zamiast wzrostu efektywności uczenia się dzięki wykorzystaniu mediów mają miejsce takie zjawiska, jak:

- spadek poziomu wiedzy na wszystkich etapach kształcenia,

- spadek czytelnictwa,

- niższe kompetencje językowe,

- nieumiejętność poszukiwania informacji w Internecie,

- zaburzenia koncentracji i uwagi - szczególnie u wielozadaniowców,

- uleganie modom, mała odporność na reklamę i manipulację,

- niska wytrzymałość psychiczna, większa usterkowość.

Rzeczywistość, w której pracuje współczesny nauczyciel, ma ogromny wpływ na podejmowane przez niego działania. Niestety zmiany w zakresie metodyki nauczania czy zwiększona personalizacja może mieć niewielki wpływ na proces kształcenia wobec tak silnych negatywnych uwarunkowań zewnętrznych.

\section{LITERATURA}

Bauman Z., Wielozadaniowi, opublikowano: http://wyborcza.pl/magazyn/1,129860,1 2958561,Wielozadaniowi.html [dostęp: 05.05.2016].

Bąk A., 2015, Korzystanie z urządzeń mobilnych przez małe dzieci w Polsce. Wyniki badania ilościowego. Warszawa, Fundacja Dzieci Niczyje. 
Demurget M., 2012, Yeleogłupianie. O zgubnych skutkach ogladania telewizji (nie tylko przez dzieci). Warszawa, Wydawnictwo Czarna Owca.

Digital in 2016, opublikowano: http://wearesocial.com/uk/special-reports/digitalin-2016 [dostęp: 3.03.2016].

Digital, Social and Mobile in 2015, opublikowano: http://wearesocial.com/uk/specialreports/digital-social-mobile-worldwide-2015 [dostęp: 2.03.2016].

Global Web Index, Mobile Web Usage Highest among Teens and Millennials, Post March 25 2015, opublikowano: http://www.globalwebindex.net/blog/mobile-webusage-highest-among-teens-and-millennials [dostęp: 14.03.2016].

IDC: prognozy rynku smartfonów w 2016 roku, opublikowano: http://www.telepolis. pl/wiadomosci/idc-prognozy-rynku-smartfonow-w-2016-roku-,2,3,35671.html [dostęp: 10.03.2016].

Levinson P., 2010, Nowe nowe media. Warszawa, Wydawnictwo WAM.

Raport podsumowujący wyniki projektów 2010-2015. Tożsamość młodzieży w kontekście komunikacji online, nowych technologii oraz informacji wizualnych, opublikowano: http:// e-lab.dynamicznatozsamosc.org/2014-2016/wp-content/uploads/2015/12/Raportpodsumowuj\%C4\%85cy-wyniki-projekt\%C3\%B3w-2010-2015.pdf [dostęp: 10.05.2016]. Sitnik M., CES 2013: nocniczek z uchwytem na ...tablet, opublikowano: http://tabliczni. pl/2013/01/ces-2013-nocniczek-z-uchwytem-na-tablet/ [dostęp: 05.05.2016].

Small G., Vorgan G., 2011, iMózg. Jak przetrwać technologiczną przemianę współczesnej umysłowości. Poznań, Wydawnictwo Vesper.

Spitzer M., 2013, Cyfrowa demencja. W jaki sposób pozbawiamy rozumu siebie i swoje dzieci. Słupsk, Wydawnictwo Dobra Literatura.

Toffler A., 1974, Szok przyszłości. Warszawa, Wydawnictwo Kurpisz.

DIGITAL STUDENT IN MODERN SCHOOL - DISCUSSION ABOUT THE CURRENT STATE OF EDUCATION

\begin{abstract}
The term "information overload", which Alvin Toffler used in his book Future Shock first published in 1970, was futuristic (Toffler, p. 316). Now, the utopian vision of Toffler has materialized. These are modern information and communication technologies that play a significant role in building up the phenomenon of information overload. The problem is how modern education should change, and where to draw the line when including new technologies in students' work.

The article contains a discussion about the diagnosis of information overload and an attempt to place the teacher in the digital world. Today's students overuse modern technology, which does not always result in better quality education.
\end{abstract}

Keywords: digital student, network environment, mobile devices, multi-tasking 